УДК 347.412

DOI https://doi.org/10.32837/pyuv.v1i3(28).333

\author{
В. М. Слома \\ кандидат юридичних наук, дочент, \\ доцент кафедри иивільного права і процесу \\ Тернопільського національного еконолічного університету
}

\title{
ДО ПИТАННЯ ПРО ПІДСТАВИ ВИНИКНЕННЯ СУБСИДІАРНИХ ЦИВІЛЬНО-ПРАВОВИХ ЗОБОВ'ЯЗАНЬ
}

За загальним правилом зобов'язання повинні виконуватись належними сторонами (кредитором i боржником). Водночас в окремих випадках $є$ вірогідність невиконання боржником свого обов'язку. Саме для уникнення негативних наслідків для кредитора до виконання зобов' язання залучається додатковий боржник, який виконає вимогу кредитора в разі невиконання обов'язку основним боржником.

Конструкція субсидіарних зобов'язань в умовах ринкової економіки створює необхідні правові умови, що забезпечують стійкість, стабільність правових зв'язків, узагалі спонукають до ïх виникнення, адже на вирішення питання про встановлення цивільних правовідносин суттєво впливає сам факт потенційної можливості задовольнити в субсидіарному (додатковому) порядку вимоги кредитора, оскільки гарантує більш високий ступінь захисту прав останнього, зростання довіри учасників цивільних правовідносин один до одного [2, с. 86].

Дослідження субсидіарних цивільно-правових зобов' язань неможливе без з'ясування їхньої правової природи, суб'єктного складу, а також підстав їх виникнення.

Питання, пов'язані з дослідженням правової природи субсидіарних зобов'язань, вивчали А.С. Бакін, М.М. Гудима-Підвербецька, Ю.Я. Крюкова, Х.Т. Насіров, С.В. Сарбаш, Д.В. Трут, К.О. Храпунова й ін.

Мета статті - дослідити підстави виникнення субсидіарних цивільно-правових зобов' язань.

Основою будь-якого цивільного правовідношення (зокрема, субсидіарного) завжди є три передумови: нормативна (наявність тієї чи іншої норми права, яка передбачає виникнення й існування зобов'язання), правосуб'єктна (наявність в осіб, які вступають у правовідношення цивільної правосуб'єктності) та фактична (наявність того чи іншого юридичного факту чи юридичного складу) [4, с. 36].

М.Д. Пленюк передумовами правовідносин (необхідними умовами), за наявності яких виникають, змінюються, припиняються зобов'язання, визначає: а) норми права та/або інші соціальні регулятори, що наділяють учасників правовідносин суб'єктивними правами та юридичними обов'яз- ками; б) юридичні факти як умови, за наявності яких виникають зобов'язальні правовідносини; в) інтерес уповноваженої особи, що полягає в набутті або відчуженні речі, укладенні договору тощо; г) поведінку (правова активність) учасників зобов' язальних правовідносин [7, с. 11].

Як випливає зі змісту ч. 1 ст. 619 Цивільного кодексу (далі - ЦК) України, субсидіарні зобов'язання можуть виникати з підстав, передбачених договором або законом. У питаннях підстав виникнення субсидіарного зобов'язання ЦК вимагає прямої вказівки в законі або договорі на наявність у тих чи інших випадках субсидіарного зобов'язання, інакше всі сумніви повинні трактуватись як відсутність субсидіарного зобов'язання. Не можна в питанні наявності субсидіарності дійти такого висновку шляхом опосередкованого тлумачення закону чи договору [10, с. 188].

Для виникнення субсидіарного зобов'язання необхідна наявність конкретного правовідношення, у якому є кредитор, основний боржник та додатковий боржник. Варто зазначити, що основний i додатковий боржники пов'язані один з одним, що дозволяє останньому за деяких умов виконати обов'язки основного боржника.

I.Ю. Шумейко вважає, що саме через співучасть у зобов'язанні субсидіарно зобов'язана особа стає боржником, субсидіарний боржник, зобов'язаний за законом чи договором, зажди буде стороною конкретного зобов'язання разом 3 основним боржником. 3 моменту виникнення обов'язку основної особи субсидіарний боржник завжди присутній у її зобов'язанні, якщо ця відповідальність грунтується на нормі закону. Якщо ж субсидіарна відповідальність виникає за договором, наприклад, договором поруки, то важко уявити собі ситуацію, у якій би особа, яка відповідає за зобов'язанням так само, як і інша зобов'язана особа, не була б боржником цього ж зобов'язання тільки через те, що черговість звернення до них за виконанням зобов'язання є послідовною, та субсидіарного боржника не можна притягнути до відповідальності раніше, ніж основного [11, с. 99].

Відповідно до ч. 2 ст. 619 ЦК України, до пред'явлення вимоги особі, яка несе субсидіарну відповідальність, кредитор повинен пред'явити вимогу до основного боржника. Якщо основний 
боржник відмовився задовольнити вимогу кредитора або кредитор не одержав від нього в розумний строк відповіді на пред'явлену вимогу, кредитор може пред'явити вимогу в повному обсязі до особи, яка несе субсидіарну відповідальність.

Як випливає зі змісту ч. 2 ст. 619 ЦК України, щоби субсидіарний боржник міг бути залучений до виконання зобов'язання, необхідно, щоб основний боржник його не виконав чи виконав його неналежно. Тобто для виникнення субсидіарного зобов' язання необхідна наявність таких підстав: виникнення відносин між основним і додатковим боржниками; виникнення відносин між кредитором i основним боржником; невиконання чи неналежне виконання зобов'язання основним боржником.

Х.Т. Насіров також робить висновок, що для договірного субсидіарного зобов'язання необхідне вчинення двох послідовних домовленостей: спочатку між боржником і третьою особою, за якою третя особа приймає на себе обов'язок покрити вірогідну можливість неналежного виконання зобов'язаною в діючому зобов'язанні стороною; згодом між кредитором і боржником зобов'язального правовідношення [6, с. 37].

Про роль договору як підстави виникнення цивільно-правових зобов'язань, зокрема й субсидіарних, свідчить те, що значна частина статей ЦК України присвячена саме йому. Н.С. Кузнєцова зазначає, що на стадії формування цивільних правовідносин і виникнення суб'єктивних цивільних прав і обов'язків договір є універсальним юридичним фактом, який може «давати життя» цивільним правовідносинам у всіх сферах, що належать до предметацивільно-правовогорегулювання[5, с. 17].

Особливості договору як юридичного факту полягають у такому:

- як і будь-який інший юридичний факт, договір запускає механізм реалізації норми;

- визначає зміст і обсяг договірного зобов'язання, виступаючи своєрідною «лінзою», крізь яку проходять закріплені в законі вказівки законодавця щодо врегулювання тих чи інших відносин, «заломлюються» під тим кутом, який є прийнятним для обох сторін;

- виступає джерелом індивідуальних правил поведінки для сторін [1, с. 66-67].

Характеризуючи договір як підставу виникнення субсидіарного зобов'язання, варто зазначити, що основним елементом є домовленість між кредитором і боржником, у якій сторони визначають умови, за яких субсидіарний боржник буде зобов'язаний виконати зобов'язання на користь кредитора в разі невиконання чи неналежного виконання зобов' язання основним боржником.

За правовою природою договір між кредитором і боржником є умовним, оскільки залучення додаткового боржника до виконання зобов'язан- ня залежить від поведінки основного боржника. Якщо основний боржник не задовольнив вимогу кредитора, тоді до виконання залучається додатковий боржник. Якщо ж зобов' язання належним чином виконав основний боржник, то воно припиняється фактом виконання без залучення додаткового боржника.

Отже, у субсидіарних зобов'язаннях, які виникають на підставі договору, важливу роль відіграє факт добровільного прийняття додатковим боржником зобов'язань основного боржника, який із певних причин не зміг належним чином виконати свої обов' язки.

У договорі повинні бути також враховані права й інтереси додаткового боржника, одним 3 яких є право на пред'явлення регресної вимоги. Крім того, як зазначає М.М. Гудима-Підвербецька, боржник має право узгодити настання таких умов, за яких основний боржник не просто компенсує субсидіарному боржнику всі витрати, пов'язані 3 виконанням його невиконаного чи неналежно виконаного зобов' язання, але й додатково виплатить певну винагороду за належне виконання такого майнового обов' язку субсидіарним боржником [3].

Варто зазначити, що принцип свободи договору надає сторонам можливість укладати договори, у яких можна передбачити субсидіарну множинність. Відповідно до ч. 1 ст. 554 ЦК України, у разі порушення боржником зобов'язання, забезпеченого порукою, боржник і поручитель відповідають перед кредитором як солідарні боржники, якщо договором поруки не встановлено додаткову (субсидіарну) відповідальність поручителя. Укладаючи договір поруки, поручитель свідомо приймає на себе ризики невиконання чи неналежного виконання зобов' язання основним боржником.

C.В. Сарбаш вказує на можливість укладення договору, за умовами якого один боржник зобов' язується виконати зобов' язання іншого боржника, не виступаючи як поручитель, а фігуруючи саме як субсидіарний боржник. Наприклад, одна будівельна компанія зобов'язується збудувати (добудувати) будинок, якщо цього не зробить інша компанія [8].

Субсидіарні зобов'язання на підставі закону виникають: а) у результаті вчинення чи настання чітко визначених законом юридичних фактів (вчинення одностороннього правочину додаткового боржника чи настання події), через які треті особи приймають на себе зобов'язання відшкодувати уповноваженій у зобов'язанні особі збитки у їх неналежно виконаній основним боржником частині; б) договірних i недоговірних відносин між кредитором і боржником, які виникли на основі цих юридичних фактів [6, с. 38].

ЦК України встановлено такі випадки субсидіарної відповідальності: ч. 5 ст. 107 - субсидіарна відповідальність юридичної особи-право- 
наступника, що утворилась унаслідок поділу; ч. 3 ст. 109 - субсидіарна відповідальність юридичної особи, що утворилась унаслідок виділу; ч. 1 ст. 119 - субсидіарна відповідальність учасників повного товариства; ч. 1 ст. 133 - субсидіарна відповідальність учасників командитного товариства; ч. 2 ст. 163 - субсидіарна відповідальність членів виробничого кооперативу.

Субсидіарну відповідальність учасників товариства 3 додатковою відповідальністю передбачено ч. 1 ст. 56 ЗУ «Про товариства з обмеженою та додатковою відповідальністю» .

Виникнення субсидіарного зобов'язання передбачено в договірних відносинах управління майном і комерційної концесії. Відповідно до ч. 2 ст. 1043 ЦК України, управитель несе субсидіарну відповідальність за боргами, що виникли у зв'язку зі здійсненням ним управління, якщо вартості майна, переданого в управління, недостатньо для задоволення вимог кредиторів. Крім того, ч. 3 ст. 1043 ЦК України встановлено, що субсидіарна відповідальність управителя, встановлена ч. 2 цієї статті, настає також у разі вчинення правочинів із перевищенням наданих йому повноважень або встановлених обмежень, за умови, що треті особи, які беруть участь у правочині, доведуть, що вони не знали і не могли знати про перевищення управителем повноважень або встановлених обмежень.

Щодо відносин комерційної концесії, то, відповідно до ст. 1123 ЦК України, правоволоділець несе субсидіарну відповідальність за вимогами, що пред'являються до користувача у зв'язку з невідповідністю якості товарів (робіт, послуг), проданих (виконаних, наданих) користувачем.

Що стосується випадків існування субсидіарного зобов'язання в корпоративних відносинах, то варто зазначити, що підставою для залучення додаткового боржника до виконання зобов'язання основного боржника є неспроможність останнього виконати таке зобов'язання.

Прикладом залучення субсидіарного боржника є відповідальність держави за боргами казенного підприємства. Відповідно до ч. 7 ст. 77 Господарського кодексу (далі - ГК) України, казенне підприємство відповідає за своїми зобов' язаннями лише коштами, що є в його розпорядженні. У разі недостатності зазначених коштів держава в особі органу, до сфери управління якого входить підприємство, несе повну субсидіарну відповідальність за зобов' язаннями казенного підприємства.

В окремих випадках для залучення субсидіарного боржника необхідною умовою $є$ також вина останнього в неможливості виконання зобов'язання основним боржником. Відповідно до ч. 6 ст. 126 ГК України, якщо корпоративне підприємство через дії або бездіяльність холдингової компанії виявиться неплатоспроможним та визнається банкрутом, то холдингова компанія несе субсидіарну відповідальність за зобов'язаннями корпоративного підприємства.

Водночас застосування відповідальності має пов'язуватися з ухваленням рішення акціонером, яке впливає на процес управління товариством, коли є вирішальний вплив. Це рішення може бути ухвалене й акціонерами, яким належить незначний пакет акцій, наприклад, у разі відсутності акціонера(ів), якому(им) належить значний пакет акцій, але за умови кворуму під час ухвалення відповідного рішення [9, с. 61].

Субсидіарна множинність може мати місце також у зобов'язаннях із відшкодування збитків. Даний вид відповідальності пов'язаний з обов'язком батьків (усиновлювачів), піклувальників компенсувати шкоду, завдану неповнолітніми особами, у разі відсутності в неповнолітнього майна, достатнього для такого відшкодування, якщо не доведуть, що шкоду було завдано не з їхньої вини (ч. 2 ст. 1179, ч. 2 ст. 1180 ЦК України).

Відповідно до п. 6 постанови Пленуму Верховного Суду України № 6 від 27 березня 1992 р. «Про практику розгляду судами цивільних справ за позовами про відшкодування шкоди», батьки (усиновителі) або опікуни несуть майнову відповідальність у випадках, коли шкода, завдана неповнолітнім, є наслідком нездійснення за ним контролю, неналежного виховання або неправильного використання щодо них своїх прав.

Субсидіарні зобов'язання виникають із підстав, передбачених договором або законом. Водночас у субсидіарних зобов'язаннях, які виникають на підставі договору, важливу роль відіграє волевиявлення суб'єктів (кредитора, основного та додаткового боржників), яке реалізується шляхом укладення договору (договорів). У договірних відносинах сторонами субсидіарного зобов' язання визначаються умови, за яких додатковий боржник буде залучатись до виконання зобов'язання, обсяг виконання, а також наслідки для сторін у разі виконання зобов'язання додатковим боржником.

Що стосується субсидіарних зобов'язань, які виникають на підставі закону, то відносини між суб'єктами регулюються імперативними приписами закону. Обов'язок додаткового боржника виконати вимогу кредитора виникає на підставі чітко визначених законом юридичних фактів.

\section{Jimepamypa}

1. Васильєва В.В. Договір як підстава виникнення цивільно-правового зобов'язання : дис. ... канд. юрид. наук: 12.00.03. Київ, 2013. 216 с.

2. Гудима-Підвербецька М.М. Субсидіарні зобов'язання в цивільному праві України: окреслення проблеми. Науковий вісник Ужгородського університету. Серія «Право». 2018. Вип. 53. Т. 1. С. 85-88.

3. Гудима-Підвербецька М.М. Щодо прояву диспозитивності в договірних субсидіарних зобов'язаннях. 
URL: https://conference.pu.if.ua/forum/viewtopic $\mathrm{php} ? \mathrm{f}=217 \& \mathrm{t}=612$.

4. Крюкова Ю.Я. Субсидиарные обязательства в гражданском праве России : дис. ... канд. юрид. наук: 12.00.03. Екатеринбург, 2013. 170 с.

5. Кузнєцова Н.С. Договір у механізмі регулювання цивільно-правових відносин. Право України. 2012. № 9. С. $12-18$.

6. Насиров Х.Т. Теоретические проблемы субсидиарных обязательств по гражданскому праву Таджикистана и России. Сравнительно-правовой аспект : дис.... докт. юрид. наук: 12.00.03. Душанбе, 2014. 372 с.

7. Пленюк М.Д. Юридичні факти як підстави виникнення цивільно-правових зобов'язань (теоретичні та практичні засади) : дис. ... докт. юрид. наук: 12.00.03. Київ, 2016. 426 с.

8. Сарбаш С.В. Обязательства с множественностью лиц и особенности их исполнения. Москва : Статут, 2004. 112 c. URL: www.lawmix.ru/commlaw/1589.

9. Сядриста I.I. Відповідальність акціонерів у рамках корпоративних відносин. Підприєлництво, господарство і право. 2019. № 2. С. 60-64.

10. Трут Д.В. Субсидіарні зобов'язання як різновид цивільно-правових зобов'язань з множинністю осіб. Університетські наукові записки. 2012. № 4 (44). С. 186-192.

11. Шумейко И.Ю. Проблемы исполнения обязательств в гражданском праве : дис. ... канд. юрид. наук: 12.00.03. Ростов-на-Дону, 2009. 244 с.

\section{Анотація}

Слома В. М. До питання про підстави виникнення субсидіарних цивільно-правових зобов'язань. - Стаття.

Сутність субсидіарного зобов'язання визначається обов'язками основного та додаткового боржника, спрямованими на задоволення вимог кредитора. Додатковий боржник зобов'язаний виконати тільки ті зобов'язання, які не були виконані основним боржником. Стаття присвячена дослідженню підстав виникнення субсидіарних цивільно-правових зобов'язань. Автором проаналізовано положення чинного вітчизняного законодавства та теоретичні розробки з даного питання. Субсидіарні зобов'язання виникають на підставі договору або закону. Водночас у законі або договорі має бути вказано на існування саме субсидіарного зобов'язання. Акцентовано увагу, що для виникнення субсидіарного зобов'язання необхідна наявність конкретного правовідношення, у якому є кредитор, основний боржник і додатковий боржник. Відповідно до положень статті 619 Цивільного кодексу України, для виникнення субсидіарного зобов'язання необхідна наявність таких підстав: виникнення відносин між основним і додатковим боржниками; виникнення відносин між кредитором і основним боржником; невиконання чи неналежне виконання зобов'язання основним боржником. Принцип свободи договору надає сторонам можливість укладати договори, у яких можна передбачити субсидіарну множинність. Обгрунтовано, що в субсидіарних зобов'язаннях, які виникають на підставі договору, важливу роль відіграє волевиявлення суб'єктів (кредитора, основного та додаткового боржників), яке реалізується шляхом укладення договору (договорів). У договірних відносинах між сторонами субсидіарного зобов'язання визначаються умови, за яких додатковий боржник буде залучатись до виконання зобов'язань, їхній обсяг, а також наслідки для сторін субсидіарного зобов'язання в разі виконання зобов'язання додатковим боржником. Зроблено висновок, що за своєю природою договір між кредитором і боржником є умовним, оскільки залучення додаткового боржника до виконання зобов'язання залежить від поведінки основного боржника. Що стосується субсидіарних зобов'язань, які виникають на підставі закону, то відносини суб'єктів один з одним регулюються імперативними приписами закону. Обов'язок додаткового боржника виконати вимогу кредитора виникає на підставі чітко визначених законом юридичних фактів.

Ключові слова: субсидіарне зобов'язання, кредитор, основний боржник, додатковий боржник, договір, закон.

\section{Summary}

Sloma V.M. Some issues in the reasons of subsidiary civil liability. - Article.

The sense of the subsidiary liability is determined by the obligations of the principal and the secondary debtor, aimed at satisfying the claims of the lender. A secondary debtor is required to fulfill obligations that had not been fulfilled by the principal debtor. The article deals with the study of the grounds for the emergence of subsidiary civil liability. The author analyzes the provisions of the current national legislation and theoretical developments on the subject. Subsidiary liability arises on the basis of a contract or law. However, the law or the contract must indicate the existence of a subsidiary liability. It is emphasized that the existence of a subsidiary liability requires the existence of a specific legal relationship in which there is a creditor, principal debtor and secondary debtor. In accordance with the provisions of Article 619 of the Civil Code of Ukraine it is necessary to have the following reasons for the emergence of subsidiary liability: the emergence of relations between the principal and additional debtors; the emergence of a relationship between the creditor and the principal debtor; default or default of the principal debtor. The principle of the freedom of a contract gives parties the opportunity to enter into contracts where a subsidiary plurality can be envisaged. It is substantiated that in the subsidiary liabilities arising from the contract, the will of the entities (creditor, principal and additional debtors), which is realized through the conclusion of the contract (contracts), plays an important role. The contractual relationship between the parties of the subsidiary liabilities determines the conditions under which the additional debtor will be involved in the performance of the obligation, their scope, and the consequences for the parties to the subsidiary liability in the case of its performance by the secondary debtor. It is concluded that the nature of the agreement between the creditor and the debtor is conditional, since the involvement of the secondary debtor in the performance of the liability depends on the conduct of the principal debtor. As for subsidiary liabilities arising from the law, the relations between the entities are governed by the imperative provisions of the law. The obligation of the secondary debtor to fulfill the claim of the creditor arises on the basis of clearly established legal facts.

Key words: subsidiary liability, creditor, principal debtor, secondary debtor, contract, law. 